\title{
Stingless bees (Meliponini): senses and behavior
}

\author{
Michael Hrncir $^{1}\left(\mathbb{D} \cdot\right.$ Stefan Jarau $^{2} \cdot$ Friedrich G. Barth $^{3}$
}

Received: 21 July 2016 / Accepted: 22 July 2016 / Published online: 12 August 2016

(C) Springer-Verlag Berlin Heidelberg 2016

\begin{abstract}
Stingless bees (Hymenoptera, Apidae, Meliponini) are by far the largest group of eusocial bees on Earth. Due to the diversity of evolutionary responses to specific ecological challenges, the Meliponini are well suited for comparative studies of the various adaptations to the environment found in highly eusocial bees. Of particular interest are the physiological mechanisms underlying the sophisticated cooperative and collective actions of entire colonies, which form the basis of the ecological success of the different bee species under the particular conditions prevailing in their respective environment. The present Special Issue of the Journal of Comparative Physiology A provides a sample of the exciting diversity of sensorial and behavioral adaptations in stingless bees, particularly concerning (1) the sensory bases for foraging, (2) chemical communication, and (3) the behavioral ecology of foraging.
\end{abstract}

Keywords Meliponini $\cdot$ Sensory physiology ·

Communication $\cdot$ Foraging $\cdot$ Adaptations

Stingless bees (Hymenoptera, Apidae, Meliponini) are by far the largest group of eusocial bees on Earth. With more than 500 described species (Michener 2013), they outmatch

Michael Hrncir

michael@ufersa.edu.br

1 Departamento de Ciências Animais, Universidade Federal Rural do Semi-Árido, Av. Francisco Mota 572, Mossoró-RN 59625-900, Brazil

2 Institute for Neurobiology, Ulm University, Helmholtzstrasse 10/1, 89081 Ulm, Germany

3 Department for Neurobiology, Faculty of Life Sciences, University of Vienna, Althanstrasse 14, 1090 Vienna, Austria the honey bees by a factor of 50 (Apidae, Apini: 11 species; Michener 2007) and even comprise twice the number of known bumble bee species (Apidae, Bombini: approximately 250 species; Michener 2007). Their pantropical distribution, through the tropical America, Africa, Southeast Asia, and Australia (Fig. 1), suggests that the Meliponini had their origin on the ancient Gondwana continent more than 100 million years ago (Sakagami 1982; Camargo and Pedro 1992). Today, the vast majority of stingless bee species is found in the Neotropics, where they represent a large taxonomic diversity (more than 400 nominate taxa in 32 existent genera) and an impressive variety of life histories (Camargo 2013).

Despite their ecological importance, primarily as pollinators in most tropical ecosystems, knowledge about the biology of stingless bees is still rather moderate as compared to that about their celebrated relatives, the honey bees. This situation has, in part, historical reasons. The first written references mentioning meliponine bees are due to Spanish and German explorers in Central and South America and arrived in Europe in the 16th century. They were followed by reports from Australia in the 17th century (Crane 1999; Engels 2009; Jones 2013). These early accounts and subsequent archeological studies, particularly in the Mesoamerican region, revealed a long and rich tradition of meliponine honey hunting and well organized beekeeping dating back to at least 300 BC (Crane 1999). In Pre-Columbian Mayan societies stingless bees even were an essential component of mythology (Fig. 2) and the management of meliponine colonies (meliponiculture) was, and still is, a central issue of indigenous ceremonials (Crane 1999; Jones 2013). More detailed studies on stingless bees by European explorers began only during the 19th century, at a time when scientific research on honey bees had already advanced for almost 200 years (Quintal and Roubik 


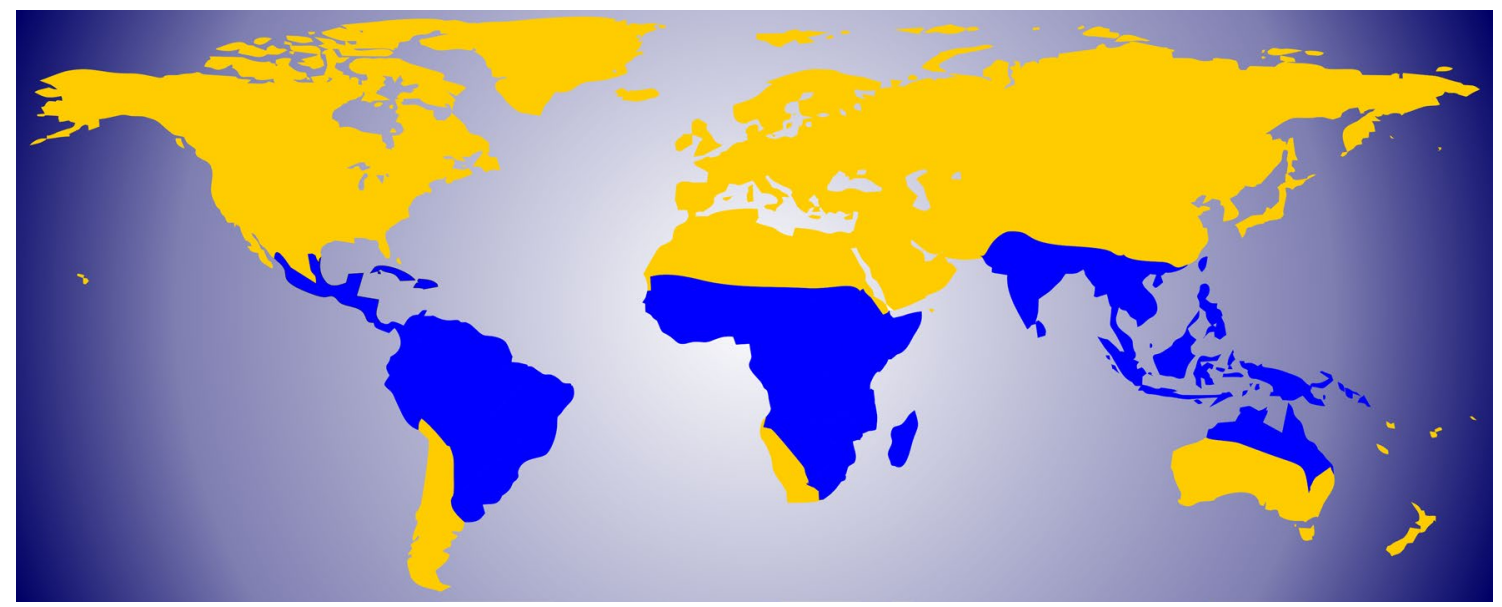

Fig. 1 Pantropical distribution (blue color) of stingless bees (Apidae, Meliponini). After Sakagami (1982)
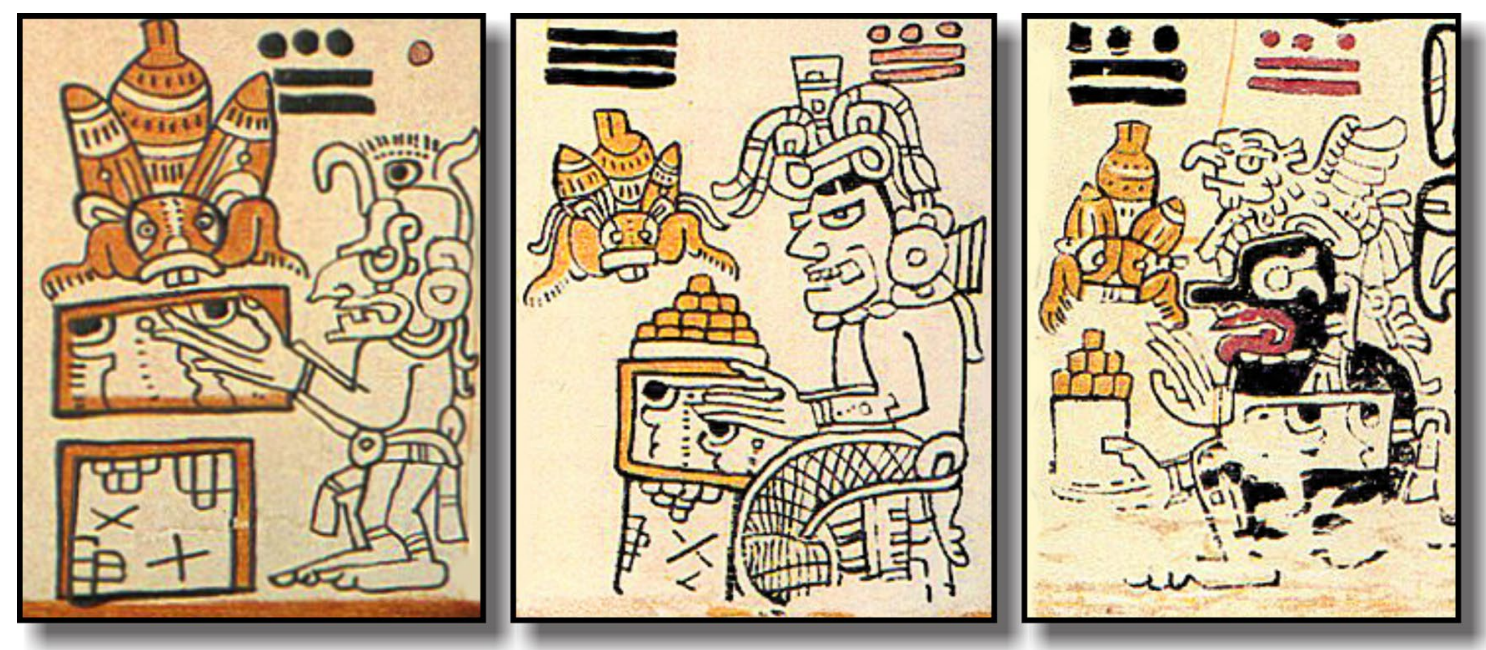

Fig. 2 Stingless bees in Mayan mythology. Representations of the Mayan bee god Ah-Muzen-Cab (to the left of each panel, in yellow or orange color) together with other gods or god-like figures holding stingless bee hives and brood or storage pots (to the right). From pages 104 (left panel), 108 (middle panel), and 109 (right panel) of the Madrid Codex (c. 900-1521 AD). Source: http://www.famsi.org/ mayawriting/codices

fact, with a vestigial and not functional sting; von Ihering 1886) and, therefore, essentially show the same physiological characteristics and behaviors. In fact, the divergent evolution of the Meliponini and the Apini for more than 100 million years since the late Cretaceous (Cardinal et al. 2010) resulted in two very distinct bee groups. Both the stingless bees and the honey bees are classified as highly eusocial (colonies with adults of two generations, castes and division of labor, cooperative work on brood cells, permanent colonies; Michener 1974). Whereas the modern Apini constitute a small and morphologically, physiologically, and behaviorally uniform group (Michener 2007), the Meliponini evolved into a highly diverse tribe. This applies to their body size (ranging from species smaller 


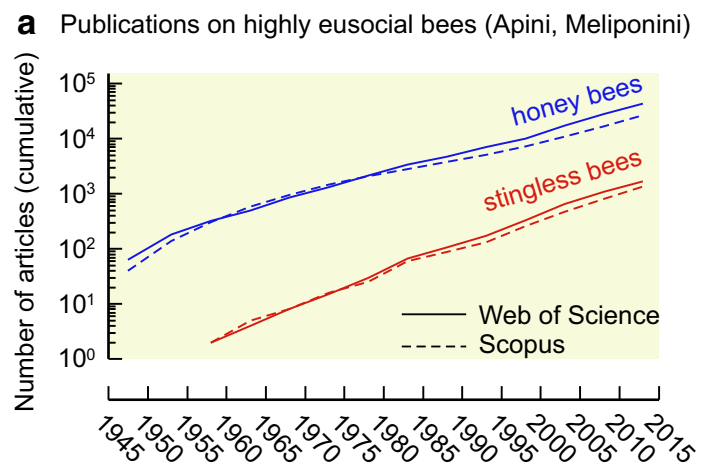

b Publications on Meliponini (relative to total on highly eusocial bees)

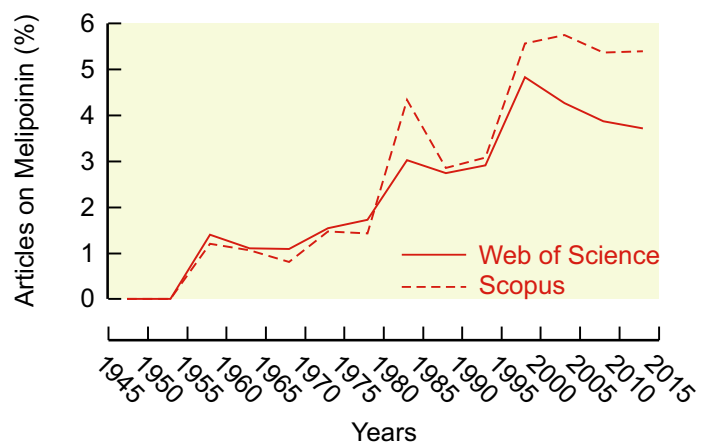

Fig. 3 Publications on highly eusocial bees (Apini and Meliponini) since 1945. a Cumulative number of publications on honey bees (blue lines) and stingless bees (red lines). b Proportion of articles on stingless bees relative to the total of publications on highly eusocial bees. Publications registered in ISI Web of Science (solid lines) and Scopus Citation Database (dashed lines). Search keywords: Apini/honeybee/ honey bee/Apis/Apini/Apinae/Honigbiene; Meliponini/stingless bee/ meliponine/Meliponina/meliponidae/sem ferrão/stachellos

than fruit flies to species larger than honey bees), colony size (number of individuals ranging from a few dozens to several thousands), nesting biology (subterranean nests; non-arboreal or arboreal cavities; association with termites, ants or wasps; exposed nests), brood cell-arrangement (horizontal or, rarely, vertical combs; irregular clusters), queen production (few queens in special brood cells; multiple queens in unspecialized cells), foraging strategy (solitary foraging; foraging in small or large groups; aggressive or unaggressive group foraging) and underlying recruitment mechanism (vibratory activation of nestmates; goaldirected guidance of nestmates through pheromones), and other still little explored traits (Michener 1974; Sakagami 1982; Johnson 1983; Wille 1983; Engels and ImperatrizFonseca 1990; Roubik 2006; Barth et al. 2008). This rich diversity may be the result of accelerated speciation rates in the tropics owing to higher mutation rates, and/or faster physiological processes at higher ambient temperatures (Currie et al. 2004). Moreover, the co-occurrence of several dozen of social bee species and their competition over common resources (food, nesting space, etc.) is believed to have resulted in the segregation of ecological niches and the obvious diversification of adaptive strategies (Roubik 1989; Biesmeijer and Slaa 2006).

Due to the diversity of their evolutionary responses to specific ecological challenges, the Meliponini are well suited for comparative studies of the various adaptations to the environment found in highly eusocial bees. Of particular interest in this context are the physiological mechanisms underlying the sophisticated cooperative and collective actions of entire colonies, which form the basis of the ecological success of the different bee species under the particular conditions prevailing in their respective environment. The present Special Issue of the Journal of Comparative Physiology A provides a sample of the exciting diversity of sensorial and behavioral adaptations in stingless bees, adding important information to recent publications on Meliponini differing in focus (scientific journals: Stingless bees: Biology and management, 2006, Apidologie 37/2; Stingless bees: Integrating basic biology and conservation, 2014, Sociobiology 61/4; books: Vit et al. 2013; Cortopassi-Laurino and Nogueira Neto 2016; Heard 2016).

The first part of the present Special Issue is dedicated to (1) "The sensory bases for foraging". It compiles information about visual and olfactory mechanisms which enable Neotropical and Australian Meliponini to cope with the sensory challenges in different foraging environments. When searching for food, visual cues are important for foragers to detect flowers from a distance. Here, color preferences (both innate and modulated through previous experience), visual acuity, spatial resolution, and light sensitivity of the bees' eyes are key physiological characteristics to identify flower patches in complex visual habitats, such as tropical rainforests (Dyer et al. 2016a, b; Koethe et al. 2016; Streinzer et al. 2016). Once at the food source, foragers need to decide which flowers to visit and which to avoid. Footprints, left by previous visitors, are important chemical cues in this context because they indicate whether or not a flower still provides the desired resource. The bees' reaction to these scent marks (attraction, avoidance) is not innate; rather, foragers quickly learn their actual meaning in each new foraging context (Roselino et al. 2016). A recently increasing anthropogenic menace concerning the sensorial and cognitive capacities of foraging bees is the indiscriminate use of agrochemicals. Exposure to sublethal doses of pesticides, for example, compromises the neuronal plasticity of bees during ontogenesis. This leads to a reduced brain volume, particularly of the mushroom bodies and optical lobes, in workers, therewith impairing their performance during foraging (Lima et al. 2016).

The second part of this Special Issue compiles information about (2) "Chemical communication". Chemical communication signals are fundamental for coordinating 
collective actions of meliponine colonies, such as colony defense and food exploitation. Mandibular gland pheromones released by workers, and also by males, when biting a potential nest-intruder trigger the collective attack of the enemy (Schorkopf 2016). Chemical communication is also important to direct groups of foragers toward specific resources. Here, foraging strategies that rely on such goal-directed recruitment usually rely on pheromone marks at and near the exploited food patch. These conspicuous chemical signals are prone to eavesdropping and, thus, may attract competitors. To avoid eavesdroppers, some meliponine species evolved alternative recruitment strategies, guiding large numbers of nestmates to food patches without using a scent trail (Flaig et al. 2016).

In the third part of our Special Issue, studies are presented that investigate the (3) "Behavioral ecology of foraging" in stingless bees. To maximize the food intake into the nest, colonies need to fine-tune their foraging strategy according to the respective environmental situation, including climatic factors, presence or absence of competitors, identity of competitors, and resource abundance and quality. Of these, climatic conditions, particularly air temperature and rain, constrain the foraging activity of a colony, yet affect different species differently. Thus, some species are able to collect resources under weather conditions that prohibit the activity of others, thereby avoiding interference competition at the food sources. In case that two or more species arrive simultaneously at a food patch, the presence of competitors, their aggressiveness and number might limit a colony's access to this specific resource (Keppner and Jarau 2016). Here, a high abundance of food sources in the environment allows the colonies to switch to alternative patches, to collect more efficiently, and to return more quickly to the nest (Leonhardt et al. 2016). An elevated resource abundance and quality of food sources within the foraging area, moreover, stimulates the colonies to raise their foraging effort, therewith increasing the food intake rate into the nest (Schorkopf et al. 2016). Interestingly, and in strict contrast to honey bees, nest-internal food storage conditions influence the colony foraging activity of stingless bees only to a minor extent (Maia-Silva et al. 2016; Schorkopf et al. 2016). The difference between these two highly eusocial bee taxa is presumably due to differences in brood care (Apini: progressive larval feeding; Meliponini: mass-provisioning of brood cells), emphasizing the fundamental differences between stingless bees and honey bees concerning the proximate mechanisms that evolved to coordinate the observed colony behavior.

Despite the steadily increasing number of scientific studies on stingless bees (Fig. 3), our knowledge about the Meliponini is still in the shadow of what we know from honey bees. In contrast to A. mellifera, which is considered an environmental generalist, many Meliponini occur in rather narrow geographic ranges (Camargo 2013), and are frequently restricted to a very specific habitat. Consequently, meliponine species often show a very strong association between their life history and a particular environmental situation. The study of stingless bees, therefore, will certainly help to reach more profound insights into how environmental factors shaped the physiological and behavioral mechanisms underlying the complex colony organization of highly eusocial bees. We very much hope that this special issue will stimulate future research on this fascinating and diverse group of eusocial bees, leading to a deeper understanding of meliponine neuroethology, as well as their sensory and behavioral physiology.

\section{References}

Barth FG, Hrncir M, Jarau S (2008) Signals and cues in the recruitment behavior of stingless bees (Meliponini). J Comp Physiol A 194:313-327

Biesmeijer JC, Slaa EJ (2006) The structure of eusocial bee assemblages in Brazil. Apidologie 37:240-258

Camargo JMF (2013) Historical biogeography of the Meliponini (Hymenoptera, Apidae, Apinae) of the Neotropical region. In: Vit P, Pedro SRM, Roubik D (eds) Pot-honey: a legacy of stingless bees. Springer, New York, pp 19-34

Camargo JMF, Pedro SRM (1992) Systematics, phylogeny and biogeography of the Meliponinae (Hymenoptera, Apidae): a minireview. Apidologie 23:509-522

Cardinal S, Straka J, Danforth BN (2010) Comprehensive phylogeny of apid bees reveals the evolutionary origins and antiquity of cleptoparasitism. Proc Natl Acad Sci USA 107:16207-16211

Cortopassi-Laurino M, Nogueira Neto P (2016) Abelhas sem ferrão do Brasil. Editora da Universidade de São Paulo, São Paulo

Crane E (1999) The world history of beekeeping and honey hunting. Routledge, New York

Currie DJ, Mittelbach GG, Cornell HV, Field R, Guégan JF, Hawkins BA, Kaufman DM, Kerr JT, Oberdorff T, O'Brien E, Turne JRG (2004) Predictions and tests of climate-based hypotheses of broad-scale variation in taxonomic richness. Ecol Lett 7:1121-1134

Dyer AG, Boy-Genry S, Shrestha M, Lunau K, Garcia JE, Koethe S, Wong BBM (2016a) Innate colour preferences of the Australian native stingless bee Tetragonula carbonaria Sm. J Comp Physiol A. doi:10.1007/s00359-016-1101-4

Dyer AG, Streinzer M, Garcia J (2016b) Flower detection and acuity of the Australian native stingless bee Tetragonula carbonaria Sm. J Comp Physiol A. doi:10.1007/s00359-016-1107-y

Engels W (2009) The first record on Brazilian stingless bees published 450 years ago by Hans Staden. Gen Mol Res 8:738-743

Engels W, Imperatriz-Fonseca VL (1990) Caste development, reproductive strategies, and control of fertility in honey bees and stingless bees. In: Engels W (ed) Social insects-an evolutionary approach to castes and reproduction. Springer, Berlin, pp $167-230$

Flaig IC, Aguilar I, Schmitt T, Jarau S (2016) An unusual recruitment strategy in a mass-recruiting stingless bee, Partamona orizabaensis. J Comp Physiol A. doi:10.1007/s00359-016-1111-2

Heard T (2016) The Australian native bee book. Sugarbag, West End

Johnson LK (1983) Foraging strategies and the structure of stingless bee communities in Costa Rica. In: Jaisson P (ed) Social insects in the tropics. Université Paris-Nord, Paris, pp 31-58 
Jones R (2013) Stingless bees: a historical perspective. In: Vit P, Pedro SRM, Roubik D (eds) Pot-honey: a legacy of stingless bees. Springer, New York, pp 219-227

Keppner EM, Jarau S (2016) Influence of climatic factors on the flight activity and competition behavior of the stingless bee Partamona orizabaensis. J Comp Physiol A. doi:10.1007/ s00359-016-1112-1

Koethe S, Bossems J, Dyer AG, Lunau K (2016) Colour is more than hue: preferences for compiled colour traits in the stingless bees Melipona mondury and M. quadrifasciata. J Comp Physiol A. doi:10.1007/s00359-016-1115-y

Leonhardt SD, Kaluza BF, Wallace H, Heard TA (2016) Resources or landmarks: which factors drive homing success in Tetragonula carbonaria foraging in natural and disturbed landscapes? J Comp Physiol A. doi:10.1007/s00359-016-1100-5

Lima MAP, Martins GF, Oliveira EE, Guedes RNC (2016) Agrochemical-induced stress in stingless bees: peculiarities, underlying basis, and challenges. J Comp Physiol A. doi:10.1007/ s00359-016-1110-3

Maia-Silva C, Hrncir M, Imperatriz-Fonseca VL, Schorkopf DLP (2016) Stingless bees (Melipona subnitida) adjust brood production rather than foraging activity in response to changes in pollen stores. J Comp Physiol A. doi:10.1007/s00359-016-1095-y

Michener CD (1974) The social behavior of the bees. Harvard University Press, Cambridge

Michener CD (2007) The bees of the world, 2nd edn. The Johns Hopkins University Press, Baltimore

Michener CD (2013) The Meliponini. In: Vit P, Pedro SRM, Roubik D (eds) Pot-honey: a legacy of stingless bees. Springer, New York, pp 3-17

Quintal RB, Roubik DW (2013) Melipona bees in the scientific world: western cultural views. In: Vit P, Pedro SRM, Roubik D (eds) Pot-honey: a legacy of stingless bees. Springer, New York, pp 247-259

Roselino AC, Rodrigues AV, Hrncir M (2016) Stingless bees (Melipona scutellaris) learn to associate footprint cues at food sources with a specific reward context. J Comp Physiol A. doi:10.1007/s00359-016-1104-1

Roubik DW (1989) Ecology and natural history of tropical bees. Cambridge University Press, New York

Roubik DW (2006) Stingless bee nesting biology. Apidologie $37: 124-143$

Sakagami SF (1982) Stingless bees. In: Hermann HR (ed) Social insects, vol III. Academic Press, New York, pp 361-423

Schorkopf DLP (2016) Male meliponine bees (Scaptotrigona aff. depilis) produce alarm pheromones to which workers respond with fight and males with flight. J Comp Physiol A. doi:10.1007/ s00359-016-1109-9

Schorkopf DLP, Sá Filho GF, Maia-Silva C, Schorkopf M, Hrncir M, Barth FG (2016) Nectar profitability, not empty honey stores, stimulate recruitment and foraging in Melipona scutellaris (Apidae, Meliponini). J Comp Physiol A. doi:10.1007/ s00359-016-1102-3

Streinzer M, Huber W, Spaethe J (2016) Body size limits dim-light foraging activity in stingless bees (Apidae: Meliponini). J Comp Physiol A. doi:10.1007/s00359-016-1118-8

Vit P, Pedro SRM, Roubik D (2013) Pot-honey: a legacy of stingless bees. Springer, New York

von Ihering $\mathrm{H}$ (1886) Der Stachel der Meliponen. Ent Nachr 12:177-188

Wille A (1983) Biology of the stingless bees. Annu Rev Entomol 28:41-64 